\title{
ЩОДО ПАРАДИГМИ ПОЄДНАННЯ СИСТЕМНО-БІОЛОГІЧНИХ І СИСТЕМНО- МЕДИЧНИХ УЯВЛЕНЬ ДЛЯ ФОРМУВАННЯ НОВОГО ПОГЛЯДУ НА ДІАГНОСТИКУ ТА ЛІКУВАННЯ ІШЕМІЧНОЇ ХВОРОБИ СЕРЦЯ
}

\author{
О. П. Мінцер, Л. Ю. Бабінцева, Н. В. Харченко \\ Національна медична академія післядипломної освіти імені П. Л. Шупика \\ Досліджено можливості створення інтелектуального мосту між даними системної біології та системної медицини. \\ Показано, що потребують створення імітаційні моделі in silico для визначення ролі тригерних реакцій, тригерних \\ каскадів у виникненні патології. Необхідна структуризація накопичених медичних знань, побудова онтологічних
} моделей знань різного рівня.

Ключові слова: системно-біологічні та системно-медичні уявлення, діагностика та лікування ішемічної хвороби серця, інтелектуальний міст, тригерні механізми, тригерні каскади.

\section{ABOUT THE PARADIGM OF COMBINING SYSTEMIC BIOLOGY AND SYSTEMIC MEDICINE REPRESENTATIONS FOR FORMING A NEW LOOK AT DIAGNOSTICS AND TREATMENT OF ISCHEMIC HEART DISEASE}

\author{
O. P. Mintser, L. Yu. Babintseva, N. V. Kharchenko \\ Shupyk National Medical Academy of Postgraduate Education
}

The possibilities of creating an intellectual bridge between the data of systemic biology and systemic medicine are explored. It is shown that creation of imitation models in silico are required to determine the role of trigger reactions, trigger cascades in the appearance of pathology. It is necessary to structure the accumulated medical knowledge, build ontological models of knowledge of different levels.

Key words: systemic biology and systemic medicine representations, diagnostics and treatment of coronary heart disease, intellectual bridge, trigger mechanisms, trigger cascades.

\section{О ПАРАДИГМЕ СОЧЕТАНИЯ СИСТЕМНО-БИОЛОГИЧЕСКИХ И СИСТЕМНО-МЕДИЦИНСКИХ ПРЕДСТАВЛЕНИЙ ДЛЯ ФОРМИРОВАНИЯ НОВОГО ВЗГЛЯДА НА ДИАГНОСТИКУ И ЛЕЧЕНИЕ ИШЕМИЧЕСКОЙ БОЛЕЗНИ СЕРДЦА}

\author{
О. П. Минцер, Л. Ю. Бабинцева, Н. В. Харченко
}

Национальная медицинская академия последипломного образования имени П. Л. Шупика

Исследованы возможности создания интеллектуального моста между данными системной биологии и системной медицины. Показано, что требуют создания имитационные модели in silico для определения роли триггерных реакций, триггерных каскадов в возникновении патологии. Необходима структуризация накопленных медицинских знаний, построение онтологических моделей знаний разного уровня.

Ключевые слова: системно-биологические и системно-медицинские представления, диагностика и лечение ишемической болезни сердца, интеллектуальный мост, триггерные механизмы, триггерные каскады.

(с) О. П. Мінцер, Л. Ю. Бабінцева, Н. В. Харченко 
Вступ. Останніми роками швидкого росту набули системна біологія та системна медицина. Головною метою напрямів стало узагальнення принципів функціонування клітин, тканин, органів та організму в цілому. Загальні теоретичні уявлення базуються на принципах математичного моделювання. Вони зазвичай включають метаболічні або сигнальні мережі.

Перспективи системної біології пов' язані зі створенням кращого розуміння складних захворювань серцево-судинної системи. Завдяки використанню методології системної медицини передбачається забезпечити міждисциплінарний та трансдисциплінарний підходи до проблем кардіології та інших напрямів медицини. Кардіологи, дослідники серцево-судинної системи, практикуючі лікарі та науковці з інших галузей знань у прагненні визначити моделі здоров'я та межі хвороб матимуть тісніші зв'язки, що тепер називаються системною медициною [30]. Однак значення системної біології та системної медицини обумовлюється більш важливими факторами, й передусім відсутністю ідеології інтеграції у сучасній медицині [2, 4].

Внутрішня медицина (internal medicine) існує вже понад 130 років, проте досі відсутнє чітке загальноприйняте визначення цього терміну. Основні принципи «інтерністики» сформульовані ще В. Ослером (William Osler, 1849-1919). Відповідно до його поглядів, інтерніст - широко освічений експерт, який працює в клініці, викладає медицину в університеті, має фундаментальну підготовку в галузі патофізіології [26].

Цей ідеал піддається сьогодні серйозній ревізії у зв'язку з розвитком біомедичних технологій, швидким їх впровадженням у практику, еволюцією клінічного мислення лікарів - від пацієнта до інструменталізму («інженерна» модель відносин лікаря і пацієнта), розвитком «вузьких» спеціальностей, субспеціальностей, зростаючою популярністю сімейної медицини. Відмітимо, що й сімейна, й внутрішня медицина починалися в контексті загальної практики, основи якої закладалися Гіппократом і включали поняття цілісного організму.

3 кінця XX століття інтенсивно обговорюється питання про майбутнє внутрішньої медицини, функції якої заміщаються на практиці субспеціалістами (кардіологами, пульмонологами, гастроентерологами, гепатологами, нефрологами тощо). Ця диференціація продовжує поглиблюватися та розширюватися. Як наслідок, намітився істотний розрив між лікарем і пацієнтом, усе менше спеціалістів, які в змозі сприйняти пацієнта як цілісний об'єкт, осмислити зв'язок між патологією різних органів і систем, зробити правильний вибір із безлічі способів впливу на патологію, що призначаються різними субспеціалістами. Відповідно $\epsilon$ серйозна підозра, що внутрішня медицина стає «зникаючою спеціальністю».

Повернемося до серцево-судинних захворювань. Складні нелінійні взаємовідносини факторів, що включають безліч екологічних і генетичних показників, обумовлюють нескінчену кількість клінічних варіантів патологічної картини. Останніми роками технологічні досягнення дозволили визначити біологічні системи на глобальному рівні, породивши надію, що в поєднанні з обчислювальними підходами можна скласти адекватну та повну модель виникнення і розвитку серцевої патології [22].

Поступово формується нова парадигма медицини, що базується на створенні методології біологічних і медичних систем, інтеграції знань у різних сучасних областях. Це призводить до кращого розуміння самих складних синдромів. Упровадження нового інструменту під назвою «системна біологія» для клінічних кардіологів і дослідників серцево-судинної системи вказує на інтегрування даних із «омікс»-наук до серцевосудинних захворювань.

Слід підкреслити, що незважаючи на успіхи в терапії реперфузії міокарда, гостре його пошкодження під час ішемії / реперфузії і, як наслідок, ішемічна серцева недостатність, є основною причиною захворюваності та смертності в промислово розвинених країнах. 3 огляду на складну патофізіологію ішемічної хвороби серця, великомасштабні неупереджені глобальні підходи, здатні ідентифікувати кілька гілок сигнальних мереж, активованих при ішемії / реперфузії міокарда, можуть бути більш успішними в пошуку нових діагностичних або терапевтичних методів із високою пропускною здатністю, враховуючи геномні дослідження, епігенетичні модифікації, а також пов'язані профілі експресії генів. Ізольований «omics»-аналіз зазвичай забезпечує масив даних, що вимагають масштабного їх зберігання, великих обчислювальних ресурсів і складних інструментів біоінформатики. Можливість інтеграції різних «отісs» дає нову надію краще зрозуміти молекулярну схему активованої ішемії міокарда, помістивши ії в контексті людської «diseasome». Оскільки зміни експресії генів серця послідовно пов'язані з патофізіологією ішемічної хвороби 
серця, інтеграція епігеномних і транскриптомних даних представляється перспективним підходом до виявлення важливих мереж захворювань [14].

Отже, застосування системного підходу до серцево-судинних захворювань надасть змогу виділити потенційні можливості й обмеження такого підходу, а також розробити рекомендації щодо оптимізації пошуку нових діагностичних або терапевтичних цілей при ішемічній хворобі серця в постгеномну епоху.

Мета роботи: створення інтелектуального мосту між технологіями та результатами системної біології та можливістю їх активного впровадження в системній медицині.

Результати та їх обговорення. Протягом останніх 10 років спостерігається суттєва зміна парадигми в розумінні механізмів атерогенезу. Зважаючи на сам результат пасивного накопичення ліпідів у стінці судин, атеросклероз тепер класифікується як активний запальний стан. Нові дані показують, що атеросклероз виникає внаслідок складного впливу генетичних, екологічних і поведінкових змінних на системне та локальне запалення через складну мережу молекул, клітин та органів. Завдяки недавнім технологічним досягненням високопродуктивних «оміксів» вже виявлено безліч генів, білків і клітин, що беруть участь в атеросклеротичному каскаді. Проте потрібно зробити ще багато кроків, щоб повністю використати цю інформацію, покращити стратифікацію та антиатеросклеротичну терапію, забезпечити безперервні зусилля з пошуку нових біомаркерів для досягнення високої діагностичної точності прогнозування серцевих захворювань, особливо ішемічної хвороби серця (IXC).

Постановка проблеми. Останніми десятиліттям інтеграційна біологія почала успішно доповнювати біологію, засновану на редукционістському підході. Одногенні або однофакторно сфокусовані підходи виявили багато компонентів біологічних систем, а також їхні властивості та взаємодії. Проте для розуміння динамічних властивостей системи окремі частини необхідно вивчати в контексті «одне з одним». Системна біологія об’єднує дані всередині або між молекулярними рівнями біологічних систем. Основною спрямованістю системної біології $є$ побудова динамічних мереж, щоб зрозуміти, як виконується біологічна функція. Прикладами біологічних мереж є генні мережі, транскрипційні мережі, білково-білкові інтерактивні мережі та метаболічні мережі [28].
Розуміння кардіоміопатії значно покращилося завдяки вдосконаленню скринінгу та виявленню дефектів генів у геномі людини, а також різноманітним новим моделям на тваринах (миші, дрозофіли) та обчислювальним моделям in silico. Ці нові експериментальні інструменти створили платформу, що є високо комплементарною природі кардіоміопатії у тварин. Повністю комплексний підхід — це значний крок вперед у розумінні молекулярних основ і патогенезу кардіоміопатії. Нарешті, нові технології, зокрема CRISPR/cas9, що вже довели свою ефективність, у даний час використовують для конструювання саркомера при кардіоміопатії у більшості тварин, зокрема свиней і приматів. Конструювання дефектів саркомерного білка кардіоміоцитів людини сприятиме подоланню розриву, щоб перевести терапевтичні мішені з дрібних тварин і в моделях in silico до хворої людини з «саркомерною» кардіоміопатією [7].

Зупинимося також на методології тригерного аналізу. Вважаємо, що тригерні механізми є одними 3 найважливіших особливостей біологічних систем. Саме вони забезпечують їх здатність перемикатися з одного режиму функціонування на інший, що відповідає кільком стійким стаціонарним станам системи. В багатьох роботах описано не тільки приклади, що демонструють можливість нелінійної біохімічної системи знаходитися в кількох можливих стаціонарних станах, але й можливості та умови переходів із одного стану в інші. Так, визначено силове та параметричне перемикання, інші варіанти переходу [1].

Сьогодні розуміння тригерних механізмів і тригерних каскадів знаходить широке застосування й у клінічній практиці.

Функціональна медицина орієнтована на пацієнта, а не на хворобу. Основними науковими концепціями патогенезу хвороби є антецеденти, тригери та медіатори. Антецеденти є факторами, генетичними або набутими, що призводять до хвороби; тригери є факторами, що провокують симптоми й ознаки хвороби; медіатори є факторами, біохімічними або психосоціальними, що сприяють патологічним змінам і дисфункціональним реакціям. Розуміння антецедентів, тригерів і медіаторів, що лежать в основі хвороби або дисфункції у кожного пацієнта, дозволяє терапії бути орієнтованою на потреби людини. Звичайний діагноз, встановлений пацієнтові, може бути корисним при визначенні правдоподібних антецедентів, тригерів або медіаторів для кожного пацієнта, але 
сам собою не є адекватним для планування догляду за пацієнтом.

Застосування моделі персоналізованого діагнозу для пацієнтів полегшує розпізнавання порушень, що характерні для людей із хронічним захворюванням. Дієта, харчування та вплив екологічних токсинів відіграють центральну роль у функціональній медицині, тому що вони можуть призводити до хвороби, провокувати симптоми та модулювати активність біохімічних медіаторів за допомогою складного і різноманітного набору механізмів. Пояснення цих механізмів є ключовим завданням функціональної медицини [15]. Методи й інструменти інформатики та математичного моделювання грають вирішальну роль у розвитку сучасних галузей молекулярної та клітинної біології, біофізики, структурної біологї, фундаментальної медицини, генної інженерії, фізіології. Однією 3 найважливіших особливостей функціонування біологічних систем є можливість перемикання з одного режиму на інший, так званий тригерний режим. Використання тригерних форматів дає можливість отримати стратегічні висновки підходів при поясненні ключових проблем життя та загибелі організму. Вивчення тригерних механізмів функціонування набуло широкого застосовування в медичних дослідженнях [24, 25, 27]. Серед таких проблем особливий інтерес представляють проблеми програмованої клітинної смерті [3].

Деякі з цих ефектів можуть виникати з плином часу, як із прискоренням прогресування атеросклерозу, або, скоріше, раптово, як із ініціюванням аритмії або інфаркту міокарда гострими запальними реакціями, зміною адгезії тромбоцитів або судинною ендотеліальною дисфункцією. Гемодинамічні фактори впливають на всі форми судинного росту. На особливу увагу заслуговує стрес, але інші чинники, такі як кругове розтягування, однаково важливі для підтримки цілісності моделі судинної мережі. Хоча ці гемодинамічні сили є визначальними факторами виникнення та структури судинної мережі, вони, зі свого боку, піддаються структурним змінам у кровоносних судинах, таким як підвищена артеріальна жорсткість при хронічній артеріальній гіпертензії та старінні. Це призводить до взаємодії між різними силами (біомеханічними силами) та судинними елементами. Хоча багато молекулярних медіаторів біомеханічних сил, як і раніше, необхідно ідентифікувати, існує безліч доказів причинної ролі цих сил у процесах росту судин. Крім того, вплив супутньої патології призводить до розладів процесів, змінивши або біомеханіку, або їх трансдукцію в біологічні сигнали. Зокрема ендотеліальна дисфункція, цукровий діабет, гіперхолестеринемія та вік впливають на механосенсибілізацію та передавання сигналів потоку, тим самим підкріплюючи їх вплив на стан здоров’я серцево-судинної системи $[13,16]$.

Застосування системної біології у такій клінічній царині, як системна медицина, засноване на ідентифікації важливих молекулярних і екологічних взаємодій, що впливають на генезис і прогресування захворювань серця. Ці взаємодії простягаються від міжмолекулярних і мережних рівнів до клінічного рівня та фенотипів. Серцево-судинні захворювання за походженням є складними та багатогранними 3 численними факторами (генетичними, молекулярними, запальними і зовнішніми - навколишнім середовищем), що активно взаємодіють [12]. Прогресування серцевої недостатністі з погляду на системну біологію вивчалося при застосуванні таких концепцій: серцева недостатність; серцева недостатність із збереженою фракцією викиду; серцева недостатність зі зниженою фракцією викиду; симпатична адренергічна система; ліпопротеїни низької щільності, мікроРНК [17].

Подальше розроблення методології персоналізованої медицини може допомогти в поліпшенні ідентифікації ризику та максимізації переваг індивідуального лікування. Обговорюються напрями розроблення ефективних стратегій прогнозування та лікування серцево-судинних захворювань 3 масштабним використанням геномних моделей метаболізму (genome-scale metabolic models GEMs), а також інших біологічних системних підходів [10]. Поломки регуляторних генетичних механізмів, що призводять до тяжких мультифакторіальних захворювань, можуть бути спровоковані не тільки функціонально неповноцінними алелями, але й мутаціями в структурних генах або генах, що забезпечують клітинний гомеостаз (гени-тригери). Особливість процесу формування будь-якого складного фенотипового прояву — наявність множинних ієрархічних рівнів його регуляції. Характерна властивість генних мереж, які функціонують у живих системах, полягає в тому, що в них регуляторна компонента на порядки більше, ніж робоча. Це стосується як метаболічної, так і генетичної компоненти генних мереж і проявляється на кожному ієрархічному рівні їх організації.

Зауважимо, що міждисциплінарність системної біології у рамках парадигми «Єдине здоров’я» 


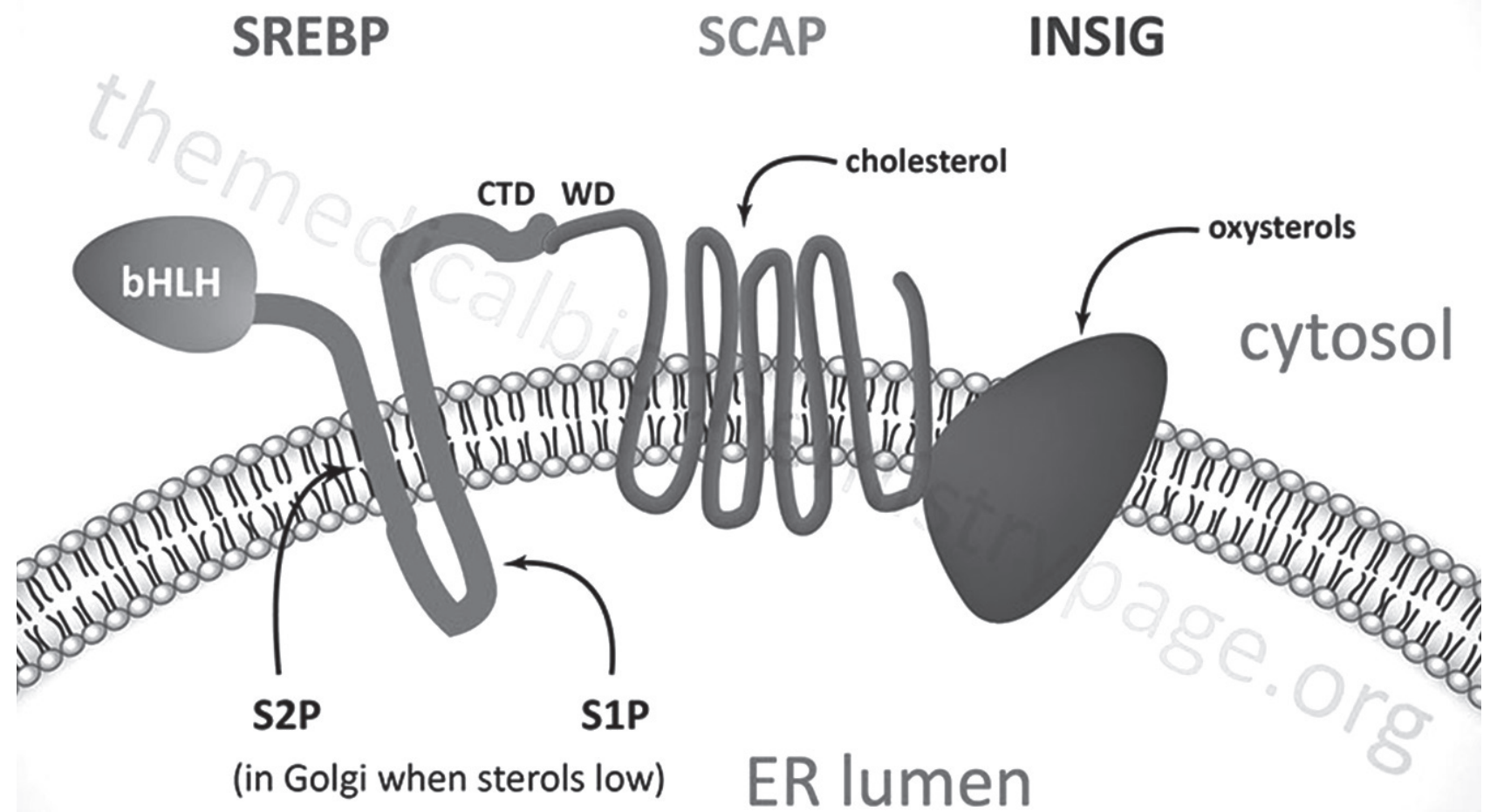

Рис. 1. Діаграмне подання взаємодій між SREBP, SCAP та Insig у мембрані ER у випадку наявності підвищених стеринів. Коли рівень стеринів низький, SCAP не взаємодіє з Insig, а комплекс SREBP-SCAP мігрує до тілець Гольджі, де знаходяться протеази, S1P i S2P. bHLH — основний спірально-петле-спіральний домен; CTD — C-термінальний домен; WD — домен WD40 [20]

(One health) підкреслює ступінь, в якій логіка єдиного здоров'я має глибоке коріння в медичних дослідженнях $[20,29]$. Частково ця дивергенція повинна відображати інституційний аспект і зростаючу складність медицини людини. Кожна база знань виросла настільки, що для практиків стало майже неможливим розглядати величезну кількість інформації, яка існує в різних видах, а також завдяки збільшенню спеціалізації («Вавілонська медична башта» [12]).

Оцінювання ризику не є єдиною точкою зору потенційної суперечки: нова орієнтація експертів у галузі охорони здоров'я людини на потенційні мікробні ризики, пов'язані з виробництвом продуктів харчування, торгівлею тваринами та екологією, може мати економічний вплив на виробників продуктів харчування [20], обмежувати ступінь можливого міждисциплінарного обміну інформацією та співпраці.

Філософія підходу представлена на прикладі генної мережі регуляції внутрішньоклітинного рівня холестерину в клітинах людини та тварин розкривається в [20].
Холестерин - незамінна структурна компонента клітинних мембран і зовнішнього шару ліпопротеїнів плазми крові, попередник цілого ряду інших стероїдів, а саме: кортикостероїдів, статевих гормонів, жовчних кислот і вітаміну D. Відхилення від нормального рівня холестерину призводить до тяжкої патології, включаючи атеросклероз судин головного мозку, серцевого м'яза й інших органів. Генна мережа регуляції внутрішньоклітинного рівня холестерину включає кілька регуляторних контурів, що функціонують за участю транскрипційних факторів сімейства SREBP (sterol regulatory elementbinding proteins). Активність транскрипційних факторів сімейства SREBP регулюється в зворотній залежності від рівня холестерину в клітині: чим вище рівень холестерину, тим нижче активність факторів SREBP. Представимо протеазо-опосередковане регулювання активації SREBP (рис. 1).

Вивільнення активного SREBP здійснюється за допомогою розщеплення, що каталізується протеазою S2P (мембранний транскрипційний фактор пептидази - MBTPS2) та відбувається у першому трансмембранному просторі. Ген MBTPS2 
розташований на X хромосомі (Хр22.12-p22.11). $\mathrm{S} 2 \mathrm{P}$ - це внутрішньомембранна металопротеаза цинку. Результатом розщеплення S2P є вивільнення N-кінцевої молекули bHLH у цитозоль. Потім домен bHLH мігрує до ядра, де він буде димеризуватися та утворювати комплекси з транскрипційними коактиваторами, що призводить до активації генів, які містять мотив SRE. Для контролю рівня SREBPопосередкованої транскрипції bHLH-ділянка піддається швидкому протеолізу.

В переліченій послідовності дій констатуємо щонайменше 5 процесів: розщеплення (що каталізується), міграція, димеризація, активація, протеоліз. Підкреслимо, що наведено самі процеси, умови ж їх реалізації залежать від багатьох факторів. Якщо зробити спробу проаналізувати можливості виконання кожного процесу в конкретній клітині, в кожній конкретній тканині, органі, організмі, можна відразу відмовитися від детермінації, а розглядати лише ймовірнісні характеристики. Отже, для кількісного визначення процесів на клітинному рівні концепція тригерно-каскадних взаємодій, що раніше розглядалася в дослідженнях, зокрема й наших, становиться вельми актуальною [5, 6, 24, 25, 27].

Для нас дуже важливою $є$ інформація, що окрім розщеплення-активації транскрипційної активності SREBP, S2P бере участь у регуляції клітинних реакцій на стрес ендоплазматичного ретикулуму, насамперед на розкриту реакцію протеїну. Також слід відзначити, що декілька білків, функції яких включають стерини, також містять SSD. У рамках патч-технології може бути приєднання холестерину та білку, що викликає хворобу Німана - Піка типу C1 (NPC1), який включає транспортування холестерину в секреторному шляху. NPC1 - це один із кількох генів, при порушенні яких виникає тяжка неврологічна дисфункція.

\section{Висновки.}

1. Потребують створення імітаційні моделі in silico для визначення ролі тригерних реакцій, тригерних каскадів у виникненні патології.

2. Необхідна структуризація накопичених медичних знань, побудова онтологічних моделей знань різного рівня.

3. Потребує створення теоретичний міст між даними системної біології та системної медицини.

\section{Література.}

1. Математическое моделирование живых систем : учебное пособие / О. Э. Соловьева, В. С. Мархасин, Л. Б. Кацнельсон [и др.] ; ред. : О. Э. Соловьева. Екатеринбург : Изд-во Уральского университета, 2013. - 328 c.

2. Мінцер О. П. Еволюція узагальнення, оброблення та передавання знань у медицині та біології / О. П. Мінцер, Д. В. Ватліцов // Медична інформатика та інженерія. - 2016. — № 1. - С. 12-14. doi: http:// dx.doi.org/10.11603/mie.1996-1960.2016.1.5904.

3. Мінцер О. П. Онтологічна модель процесів програмованої клітинної загибелі / О. П. Мінцер, Д. В. Ватліцов // Медична інформатика та інженерія. — 2015. — № 2. - С. 14-26.

4. Мінцер О. П. Про загальне впорядкування медикобіологічних знань. Створення онтології / О. П. Мінцер, Л. Ю. Бабінцева // Медична інформатика та інженерія. — 2014. — № 2. - С. 5-8.

5. Мінцер О. П. Фотоактивність біологічних молекул як можливий фактор корегування тригер залежних системних процесів (перше повідомлення) / О. П. Мінцер, Д. В. Ватліцов // Медична інформатика та інженерія. — 2015. — № 4. - С. 7-10.

6. Мінцер О. П. Щодо межі доцільності використання поняття «тригерні взаємодії» у біології та медицині. Перше повідомлення - постановка проблеми / О. П. Мінцер, К. М. Ігрунова // Медична інформатика та інженерія. — 2014. — № 4. - С. 14-22.

7. Animal and in silico models for the study of sarcomeric cardiomyopathies / D. J.Duncker, J. Bakkers, B. J. Brundel [et al.] // Cardiovasc. Res. — 2015. Vol. 105, No. 4. - P. 439-448.

8. A systems biology and proteomics-based approach identifies SRC and VEGFA as biomarkers in risk factors mediated coronary heart disease / A. Vincent, P. G. Nayar, R. Murugesan. [et al.] // Mol. Biosyst. 2016. — Vol. 12, No. 8. -P. 2594-2604.

9. Auffray C. Systems medicine: the future of medical genomics and healthcare / C. Auffray, Z. Chen, L. Hood // Genome Med. — 2009. — Vol. 1, No. 1. — P. 2.

10. Björnson E. Personalized cardiovascular disease prediction and treatment - a review of existing strategies and novel systems medicine tools / E. Björnson, J. Borén, A. Mardinoglu // Front. Physiol. — 2016. — Vol. 7. - P. 2.

11. Bressler V. Medical humanism and professionalism teaching in a community hospital since World War II / V. Bressler // The Pennsylvania Medical Humanities Consortium: Through the Lens of Time: Perspectives on Medicine and Health Care (Philadelphia, May 19-20, 2010). — Philadelphia, 2010.

12. Cholesterol / The medical biochemistry page. 2017, December 15. - Retrieved from : https:// themedicalbiochemistrypage.org/cholesterol.php. 
13. Dorn G. W. Protein kinase cascades in the regulation of cardiac hypertrophy / G. W. Dorn, T. Force // J. Clin Invest. - 2005. - Vol. 115, No. 3. -P. 527-537.

14. Epigenomic and transcriptomic approaches in the post-genomic era: path to novel targets for diagnosis and therapy of the ischemic heart? Position Paper of the European Society of Cardiology Working Group on Cellular Biology of the Heart / C. Perrino, A. L. Barabási, G. Condorell [et al.] // Cardiovasc. Res. - 2017. — Vol. 113, No. 7.- P. 725-736.

15. Galland L.. Patient-centered care: antecedents, triggers, and mediators / L. Galland // .Altern. Ther. Health Med. - 2006. - Vol. 12, No. 4. - P. 62-70.

16. Hoefer I. E. Biomechanical factors as triggers of vascular growth /I. E. Hoefer. B. den Adel, M. J. Daemen // Cardiovasc. Res. - 2013. - Vol. 99, No. 2. — P. 276283.

17. How implementation of systems biology into clinical trials accelerates understanding of diseases / B. Bielekova, Y. Vodovotz, G. An, J. Hallenbeck // Front. Neurol. — 2014. - Vol. 5. - P. 102.

18. Integrating system biology models and biomedical anthologies / R. Hoehndorf, M. Dumontier, J. H. Gennari [et al.] // BMC System Biology. — 2011. — Vol. 5. — P. 124.

19. Ion channels and transporters in cancer. 5. Ion channels in control of cancer and cell apoptosis / V. Lehen'kyi, G. Shapovalov, R. Skryma, N. Prevarskaya // Am. J. Physiol. Cell Phisiol. — 2011.— Vol. 301, No. 6. — P. 1281-1289.

20. Kahn L. H. 'One health' in action series: nos 1-8/ L. H. Kahn, B. Kaplan, T. P. Monath // Vet. Ital. 2009. - Vol. 45, No. 1. - P. 195-208.

21. Louridas G. E. Conceptual foundations of systems biology explaining complex cardiac diseases / G. E. Louridas, K. G. Lourida // Healthcare. — 2017. — Vol. 5, No. 1. - P. E10.

22. MacLellan W. R. Systems-based approaches to cardiovascular disease / W. R. MacLellan, Y. Wang, A. J. Lusis // Nat. Rev. Cardiol. — 2012. — Vol. 9, No. 3. - P. 172-184.

23. Mast F. D. Systems cell biology / F. D. Mast, A. V. Ratushny, J. D. Aitchison // J. Cell. Biol. 2014. - Vol. 206, No. 6. - P. 695-706.

24. Muller J. E. Circadian variation and triggers of onset of acute cardiovascular disease / J. E. Muller, G. H. Tofler, P. H. Stone // Circulation. — 1989. — Vol. 79, No. 4. P. 733-743.

25. Opening of mitochondrial K(ATP) channels triggers the preconditioned state by generating free radicals / T. Pain, X. M. Yang, S. D. Critz [et al.] // Circ. Res. — 2000. Vol. 87, No. 6. - P. 460-466.

26. Osler $\mathrm{W}$. The principles and practice of medicine: designed for the use of practitioners and students of medicine / W. Osler, T. McCrae. - N. Y., London : Appleton \& Company, 1920. — 9th ed. — 1168 p.
27. Oxygen radicals trigger activation of NF-B and AP-1 and up regulation of ICAM-1 in reperfused canine heart / H. Fan. B. Sun, Q. Gu [et al.] // Am. J. Physiol. Heart Circ. Physiol. — 2002. — Vol. 282. — P. H1778-H1786.

28. Sperling S. R. Systems biology approaches to heart development and congenital heart disease / S. R. Sperling // Cardiovasc. Res. — 2011. — Vol. 91, No. 2. - P. 269-278.

29. Teaching “one medicine, one health” / L. H. Kahn, B. Kaplan, T. P. Monath, J. H. Steele // Am. J. Med. 2008. - Vol. 121, No. 3. - P. 169-170.

30. The paradigm of systems biology applied to cardiovascular diseases / E. T. Mesquita, E. N. Silva, A. J. L. Jorge [et al.] // Int. J. Cardiovasc. Sci. 2015. — Vol. 28, No. 1. - P. 78-86.

\section{References.}

1. Solov'eva, O. E., Markhasin, B. C., Katsnel'son, L. B., Sul'man, T. B., Vasil'eva, A. D., \& Kursanov, A. G. (2013). Matematicheskoe modelirovanie zhivykh sistem [Mathematical modeling of living systems]: a textbook. Ekaterinburg: The Ural University Publ.

2. Mintser, O. P., \& Vatlitsov, D. V. (2016). Evolyutsiya uzagal'nennya, obroblennya ta peredavannya znan' $\mathrm{u}$ meditsini ta biologii [Evolution of generalization, processing and transfer of knowledge in medicine and biology]. Medichna informatika ta inzheneriya (Medical Informatics and Engineering), 1, 1-14. doi: http://dx.doi. org/10.11603/mie.1996-1960.2016.1.5904.

3. Mintser, O. P., \& Vatlitsov, D. V. (2015). Ontologichna model' protsesiv programovanoi klitinnoi zagibeli [Ontological model of programmed cell death processes]. Medichna informatika ta inzheneriya (Medical Informatics and Engineering), 2, 14-26.

4. Mintser, O. P., \& Babintseva, L. Yu. (2014). Pro zagal'ne vporyadkuvannya mediko-biologichnikh znan'. Stvorennya ontologii [On the general ordering of medical and biological knowledge. Creating an ontology]. Medichna informatika ta inzheneriya (Medical Informatics and Engineering), 2, 5-8.

5. Mintser, O. P., \& Vatlitsov, D. V. (2015). Fotoaktivnist' biologichnikh molekul yak mozhlivii faktor koreguvannya triger zalezhnikh sistemnikh protsesiv (pershe povidomlennya) [Photoactivity of biological molecules as a possible factor for adjusting the triggerdependent system processes (first message)]. Medichna informatika ta inzheneriya (Medical Informatics and Engineering), 4, 7-10.

6. Mintser, O. P., \& Igrunova, K. M. (2014). Shchodo mezhi dotsil'nosti vikoristannya ponyattya «trigerni vzaemodii» u biologii ta meditsini. Pershe povidomlennya postanovka problemi [On the limits of the expediency of using the concept of «trigger interactions» in biology and medicine. The first message - the statement of the problem]. Medichna informatika ta inzheneriya (Medical Informatics and Engineering), 4, 14-22. 
7. Duncker, D. J., Bakkers, J., Brundel, B. J., Robbins, J, Tardiff, J. C., \& Carrier, L. (2015). Animal and in silico models for the study of sarcomeric cardiomyopathies. Cardiovasc. Res., 105(4), 439-448. doi: 10.1093/cvr/ crv006.

8. Vincent A., Nayar, P. G., Murugesan, R., Krishnan, J, \& Ahmed, S. S. (2016). A systems biology and proteomics-based approach identifies SRC and VEGFA as biomarkers in risk factors mediated coronary heart disease. Mol. Biosyst., 12(8), 2594-2604. doi: 10.1039/ c6mb00264a.

9. Auffray, C., Chen, Z., \& Hood, L. (2009). Systems medicine: the future of medical genomics and healthcare. Genome Med., 1(1), 2. doi:10.1186/gm1.

10. Björnson, E., Borén, J., Mardinoglu, A. (2016). Personalized cardiovascular disease prediction and treatment - a review of existing strategies and novel systems medicine tools. Front. Physiol., 7, 2. doi: 10.3389/fphys.2016.00002.

11. Bressler, V. (2010). Medical humanism and professionalism teaching in a community hospital since World War II. In: The Pennsylvania Medical Humanities Consortium: Through the Lens of Time: Perspectives on Medicine and Health Care. Philadelphia (May 19-20, 2010).

12. The medical biochemistry page. (2017, December 17). Cholesterol. Retrieved from https:// themedicalbiochemistrypage.org/cholesterol.php.

13. Dorn, G. W., \& Force, T. (2005). Protein kinase cascades in the regulation of cardiac hypertrophy. J. Clin. Invest., 115(3), 527-537. doi: 10.1172/JCI200524178.

14. Perrino, C, Barabási, A. L., Condorell, G., Davidson, S. M., De Windt, L., Dimmeler, S., Engel, F. B., ... Ferdinandy, P. (2017). Epigenomic and transcriptomic approaches in the post-genomic era: path to novel targets for diagnosis and therapy of the ischemic heart? Position Paper of the European Society of Cardiology Working Group on Cellular Biology of the Heart. Cardiovasc. Res., 113(7), 725-736. doi: 10.1093/ cvr/cvx070.

15. Galland, L. (2006). Patient-centered care: antecedents, triggers, and mediators. Altern. Ther. Health Med., 12(4), 62-70.

16. Hoefer, I. E., den Adel, B, \& Daemen, M. J. (2013). Biomechanical factors as triggers of vascular growth. Cardiovasc. Res., 99(2), 276-283. doi: org/10.1093/cvr/ cvt089.

17. Bielekova, B., Vodovotz, Y., An, G., \& Hallenbeck, J. (2014). How implementation of systems biology into clinical trials accelerates understanding of diseases. Front. Neurol., 5, 102. doi: 10.3389/fneur.2014.00102.

18. Hoehndorf, R., Dumontier, M., Gennari, J. H., Wimalaratne, S., de Bono, B., Cook, D. L., \& Gkoutos, G. V. (2011). Integrating system biology models and biomedical anthologies. BMC System Biology, 5, 124. doi: 10.1186/1752-0509-5-124.
19. Lehen’kyi, V., Shapovalov, G., Skryma, R., \& Prevarskaya, N. (2011). Ion channels and transporters in cancer. 5. Ion channels in control of cancer and cell apoptosis. Am. J. Physiol. Cell Phisiol., 301(6), 1281-1289. doi: 10.1152/ajpcell.00249.2011.

20. Kahn, L. H., Kaplan, B., \& Monath, T. P. (2009). 'One health' in action series: nos 1-8. Vet Ital., 45(1), 195-208.

21. Louridas, G. E., \& Lourida, K. G. (2017). Conceptual foundations of systems biology explaining complex cardiac diseases. Healthcare, 5(1), E10. doi: 10.3390/ healthcare5010010.

22. MacLellan, W. R., Wang, Y., \& Lusis, A. J. (2012). Systems-based approaches to cardiovascular disease. Nat. Rev. Cardiol., 9(3), 172-184. doi: 10.1038/ nrcardio.2011.208.

23. ast, F. D., Ratushny, A. V. \& Aitchison, J. D. (2014). Systems cell biology. J. Cell. Biol., 206(6), 695-706. doi: 10.1083/jcb.201405027.

24. Muller, J. E., Tofler, G. H., \& Stone, P. H. (1989). Circadian variation and triggers of onset of acute cardiovascular disease. Circulation, 79(4), 733-743. doi.org/10.1161/01.CIR.79.4.

25. Pain, T., Yang, X. M., Critz, S. D., Yue, Y., Nakano, A., Liu, G. S., Heusch, G., ... Downey, J. M. (2000). Opening of mitochondrial K(ATP) channels triggers the preconditioned state by generating free radicals. Circ. Res., 87(6), 460-466. doi: org/10.1161/01. RES.87.6.460.

26. Osler, W., \& McCrae, T. (1920). The principles and practice of medicine: designed for the use of practitioners and students of medicine. 9th ed. N. Y., \& London: Appleton \& Company.

27. Fan, H., Sun, B., Gu, Q., Lafond-Walker, A., Cao, S., \& Becker, L. C. (2002). Oxygen radicals trigger activation of NF-B and AP-1 and up regulation of ICAM-1 in reperfused canine heart. Am. J. Physiol. Heart Circ Physiol., 282, H1778-H1786. doi: 10.1152/ ajpheart.00796.2000.

28. Sperling, S. R. (2011). Systems biology approaches to heart development and congenital heart disease. Cardiovasc. Res., 91(2), 269-278. doi: 10.1093/cvr/ cvr126.

29. Kahn, L. H., Kaplan, B., Monath, T. P., \& Steele, J. H. (2008). Teaching “one medicine, one health". Am. J. Med., 121(3), 169-170. doi: 10.1016/j. amjmed.2007.09.023.

30. Mesquita, E. T., Silva, E. N., Jorge, A. J., de Melo Mariano, B.; Cassino J. P.; Souza, C. V. Jr; ... Rocha, R. G. (2015). The paradigm of systems biology applied to cardiovascular diseases. Int. J. Cardiovasc. Sci., 28(1), 78-86. doi: org/10.5935/2359-4802.20150011. 